\title{
Analisis Daya Dukung Fondasi Dangkal Menggunakan Metode Numerik dan Analitik pada Tanah Lempung Lunak yang Diperkuat dengan Granular Trench
}

\author{
EGA AHMAD ROBBANI, IKHYA \\ Jurusan Teknik Sipil Institut Teknologi Nasional \\ Email : egaahmad19@gmail.com
}

\begin{abstract}
ABSTRAK
Kapasitas daya dukung adalah kemampuan fondasi dalam menahan beban struktur diatasnya. Granular trench merupakan salah satu metode perbaikan tanah. Berdasarkan hasil analisis, bahwa semakin besar kedalaman fondasi $\left(D_{f}\right)$ maka semakin meningkat kapasitas daya dukungnya, batasan pengaruh elevasi muka air tanah terhadap kapasitas daya dukung fondasi berada di sekitar kurang dari $1 B$, nilai kapasitas daya dukung fondasi maksimum berada pada kedalaman granular trench $H=3,5 B$ dan lebar granular trench $W=2 B$. Terdapat keterbatasan dalam metode analitik Hamed, Das and Echelberger yang disebabkan variabel yang tidak diperhitungkan, sedangkan metode analitik Madhav and Vitkar's selalu menghasilkan nilai kapasitas daya dukung fondasi yang lebih besar dibandingkan dengan metode lainnya, akan tetapi apabila nilai kapasitas daya dukung direduksi dengan nilai faktor koreksi 0,4-0,5 maka nilai kapasitas daya dukung fondasi akan menyerupai metode numerik. Besarnya peningkatan nilai kapasitas daya dukung maksimum setelah diperkuat granular trench adalah 355,2\%.
\end{abstract}

Kata kunci: kapasitas daya dukung, fondasi dangkal, granular trench.

\begin{abstract}
The bearing capacity is the ability of the foundation to withstand the weight of the structure above it. Granular trench were a method of soil improvement. Based on the results of the analysis, that the greater the depth value of the foundation $\left(D_{f}\right)$, the more the bearing capacity were increased, the limit of the influence of groundwater level on the bearing capacity is less than $1 B$, the maximum bearing capacity is at the depth of granular trench $H=3.5 \mathrm{~B}$ and the width of the granular trench $W=2 B$. There are limitations in the analytical method of Hamed, Das and Echelberger due to variables that are not taken into account, while the Madhav and Vitkar's analytical method always produces a greater capacity bearing capacity of the foundation compared to other methods, but if the bearing capacity value is reduced by the value of the correction factor 0.4-0.5 then the value of the foundation bearing capacity will resemble a numerical method. The magnitude of the increase in the value of the maximum bearing capacity after reinforced trench granular is $355.2 \%$.
\end{abstract}

Keywords: bearing capacity, shallow foundation, granular trench. 


\section{PENDAhUlUAN}

Penempatan fondasi sering kali menemukan suatu kondisi yang tidak diharapkan, salah satunya penempatan fondasi pada tanah lempung lunak sehingga kebutuhan nilai kapasitas daya dukung fondasi tidak tercapai yang berakibat perlu adanya perbaikan tanah, oleh karena itu diperlukan analisis lebih lanjut mengenai hal tersebut. Fondasi merupakan bagian struktur bagian paling bawah dari suatu bangunan yang tertanam di dalam lapisan tanah yang kuat dan stabil serta berfungsi sebagai penopang bangunan (Budi, 2011). Fondasi yang direncanakan harus mampu menyalurkan beban struktur bangunan diatasnya kemudian mendistribusikan beban ke lapisan tanah dibawahnya, tanpa mengalami keruntuhan geser (shear failure) dan penurunan (settlement) yang berarti.

Terdapat banyak kasus-kasus khusus mengenai permasalahan fondasi dangkal di lapangan. Granular trench adalah salah satu metode perbaikan tanah yang bertujuan untuk meningkatkan kapasitas daya dukung tanah pada tanah lempung lunak, perlu adanya kajian khusus mengenai kasus tersebut.

Maksud dan tujuan penelitian ini adalah melakukan analisis kapasitas daya dukung fondasi dangkal pada tanah lempung lunak yang diperkuat dengan tanah berbutir (granular trench) yang dipengaruhi oleh muka air tanah, kedalaman perbaikan tanah granular trench $(H)$, lebar granular trench $(W)$ dan kedalaman fondasi $\left(D_{f}\right)$ dengan menggunakan metode perhitungan analitik dan numerik.

\section{TINJAUAN PUSTAKA}

\subsection{Fondasi Dangkal yang Diperkuat Granular Trench}

Dalam pengaplikasian di lapangan, ada beberapa teknik untuk meningkatkan kapasitas daya dukung tanah pada tanah lempung lunak, Salah satu teknik tersebut adalah penggunaan ( granular trench) pada bagian bawah dasar fondasi dangkal. Gambar 1 menunjukkan sebuah gambaran fondasi dangkal dengan granular trench pada tanah lempung lunak. Lebar granular trench $(W)$, lebar fondasi $(B)$, dan kedalaman granular trench adalah $H$. Lebar granular trench $(W)$ dapat lebih kecil atau lebih besar dari lebar fondasi $B$.

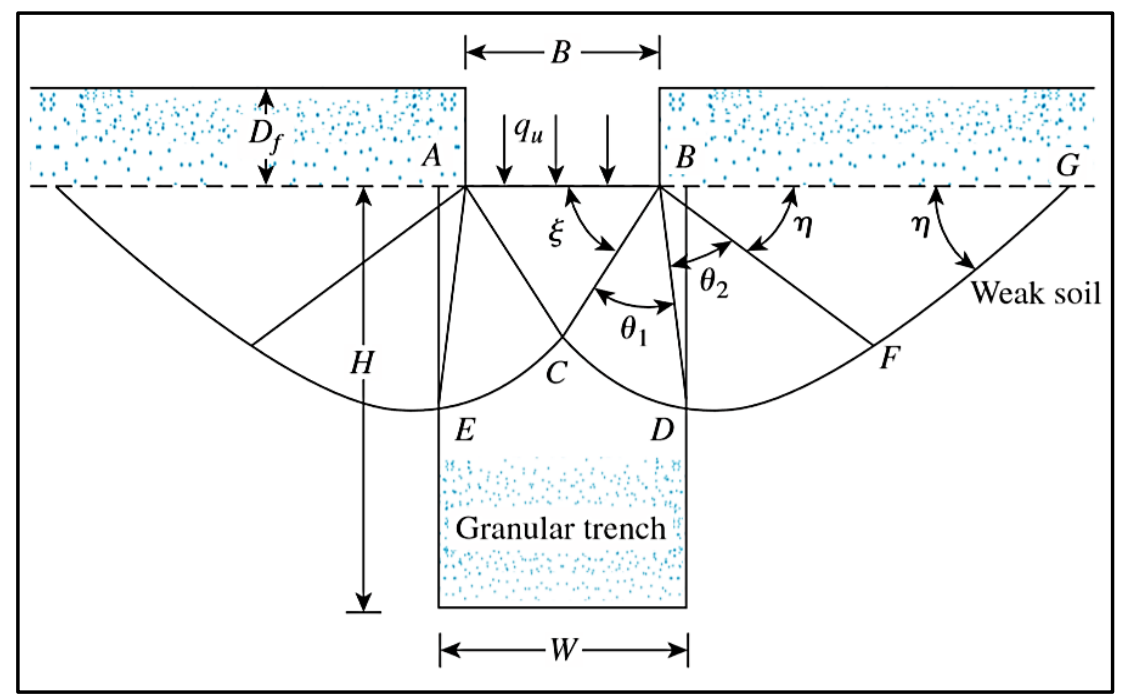

Gambar 1. Fondasi menerus pada tanah lempung lunak dengan granular trench (Sumber: Das, 2014) 
Madhav dan Vitkar (1978) diasumsikan mekanisme kegagalan umum geser dalam tanah di bawah fondasi untuk menganalisis kapasitas daya dukung tanah menggunakan analisis pola keruntuhan terikat atas batasan yang ditampilkan dalam Gambar 1. Dicatat bahwa $\theta_{1}$ dan $\theta_{2}$ fungsi $\zeta, \eta, W / B$, dan $\phi_{1}$. Dengan menggunakan teorema analisis batasan pola keruntuhan, Madhav dan Vitkar (1978) menyatakan sebagai akhir kapasitas daya dukung fondasi seperti pada Persamaan 1 berikut ini.

$$
q_{u}=c_{2} N_{c(T)}+D_{f} \gamma_{2} N_{q(T)}+\left(\frac{\gamma_{2} B}{2}\right) N_{\gamma(\mathrm{T})}
$$

halmana:

$q_{u} \quad=$ kapasitas daya dukung ultimate $[\mathrm{kN} / \mathrm{m}]$,

$c_{2} \quad=$ kohesi tanah $\left[\mathrm{kN} / \mathrm{m}^{2}\right]$,

$D_{f} \quad=$ kedalaman fondasi $[\mathrm{m}]$,

$\gamma_{2}=$ berat jenis tanah $\left[\mathrm{kN} / \mathrm{m}^{3}\right]$,

$B=$ lebar fondasi [m],

$N_{q(T)}=$ faktor daya dukung akibat beban terbagi rata pada granular trench,

$N_{c(T)} \quad=$ faktor daya dukung akibat kohesi pada granular trench,

$N_{\gamma(T)}=$ faktor daya dukung akibat berat tanah pada granular trench.

Karena Persamaan 1 menghasilkan nilai-nilai yang tidak aman daya dukung ultimate, Hamed, Das dan Echelberger menyarankan prosedur untuk memperkirakan $q_{u}$ maksimum (untuk $c_{1}=$ $0, c_{2}=c_{u}, \phi_{2}=0$, dan $B=W$ ). Prosedur ini dapat dijelaskan dengan mengacu pada Gambar 2, di mana $A$ dan $B$ adalah dua unsur hara (tanah). Untuk tanah elemen $A$, tegangan pokok adalah $\sigma_{1 f}$ dan tegangan kecil $\sigma_{i i i}$ dan persamaannya ditunjukkan pada Persamaan 2.

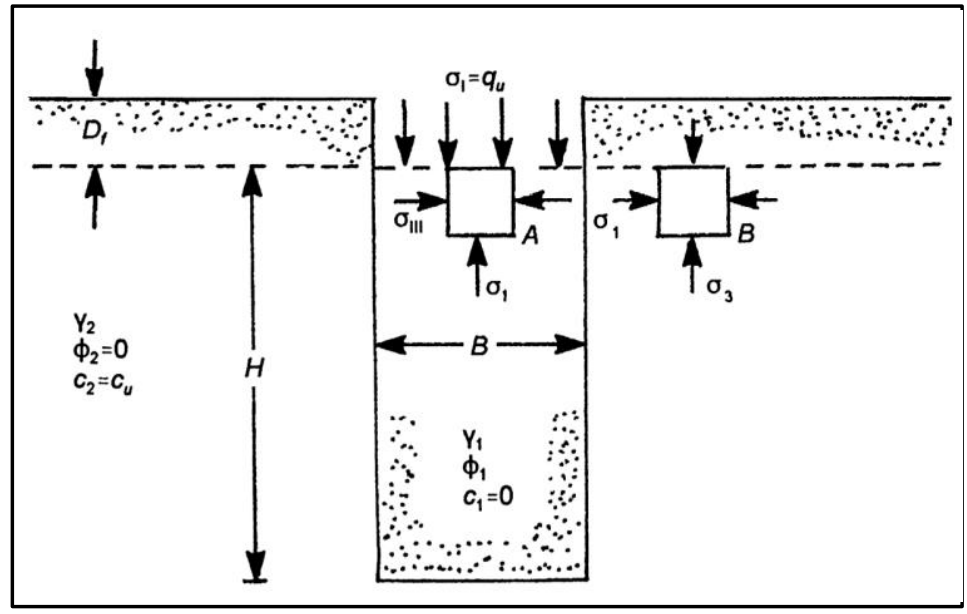

Gambar 2. Derivasi persamaan 2

(Sumber: Das, 1999)

$$
q_{u}=K_{p}(1)\left(\gamma_{2} D_{f}+2 c_{u}\right)=\left(\gamma_{2} D_{f}+2 c_{u}\right) \tan 2\left(45+\frac{\phi_{1}}{2}\right)
$$

halmana:

$q_{u} \quad=$ kapasitas daya dukung ultimate $[\mathrm{kN} / \mathrm{m}]$,

$c_{u} \quad=$ kohesi tanah $\left[\mathrm{kN} / \mathrm{m}^{2}\right]$,

$D_{f} \quad=$ kedalaman fondasi $[\mathrm{m}]$,

$\gamma_{2}=$ berat jenis tanah $\left[\mathrm{kN} / \mathrm{m}^{3}\right]$,

$\phi \quad=$ sudut geser [rad]. 


\subsection{Finite Element Method (FEM) PLAXIS 2D}

PLAXIS 2D merupakan program elemen hingga dua dimensi yang dikembangkan untuk analisis deformasi, stabilitas dan aliran air tanah dalam rekayasa geoteknik. Program ini dilengkapi dengan fitur untuk menangani berbagai aspek struktur geoteknik dan proses konstruksi menggunakan prosedur komputasi.

Langkah awal yang dilakukan adalah melakukan pemodelan menggunakan model regangan bidang (plane strain) atau axisymmetry sesuai kasus yang akan dianalisis seperti yang ditunjukkan pada Gambar 3.

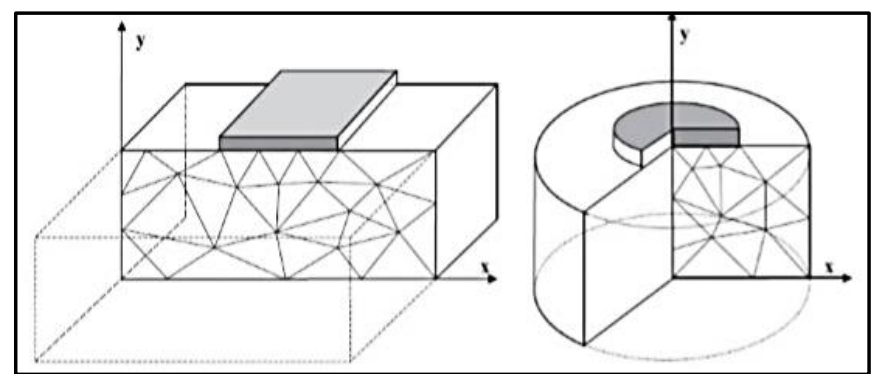

Gambar 3. Contoh regangan bidang plane strain dan axisymmetry (Sumber: PLAXIS, 2016a)

Dalam keadaan tegangan umum, model tegangan regangan berperilaku linear dalam rentang elastis. Mohr-Coulomb menghasilkan permukaan pada ruang tegangan utama seperti yang ditunjukkan pada Gambar 4. Parameter tanah yang digunakan dalam Mohr-Coulomb model yaitu $E$ (modulus elastisitas Young's), $v$ (poisson's ratio), $\phi$ (sudut geser tanah), $c$ (kohesi tanah), dan $\psi$ (sudut dilatasi).

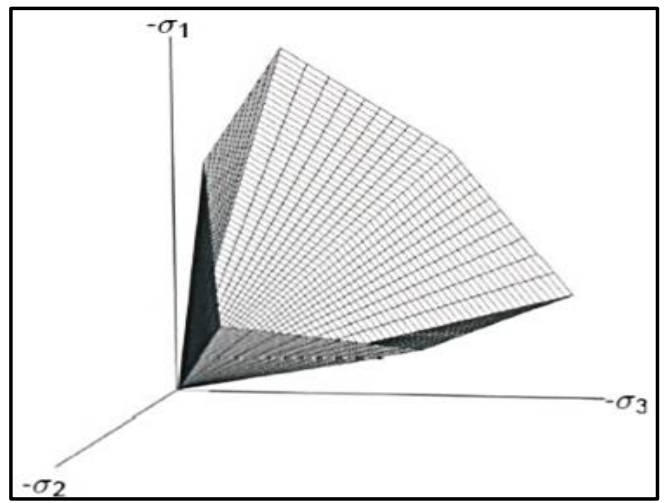

\section{Gambar 4. Kurva Mohr-Coulomb soil model (Sumber: PLAXIS, 2016b)}

\section{METODE PENELITIAN}

\subsection{Umum}

Parameter tanah dan dimensi fondasi yang sama pada setiap variasi yang akan dilakukan, variabel yang terkunci saat variasi dilakukan yaitu muka air tanah $0 B$, kedalaman fondasi $D_{f}=0 B$, lebar perbaikan tanah $W=1 B$, kedalaman perbaikan tanah $H=1 B$, bertujuan untuk mengetahui seberapa besar pengaruh masing-masing variabel yang divariasikan terhadap kapasitas daya dukung tanah. Dalam metode penelitian terdapat beberapa tahapan untuk mempermudah penelitian kapasitas daya dukung fondasi dangkal pada tanah lempung lunak yang diperkuat granular trench diantaranya yang akan dibahas menggunakan bagan alir yang dapat dilihat pada Gambar 5. 


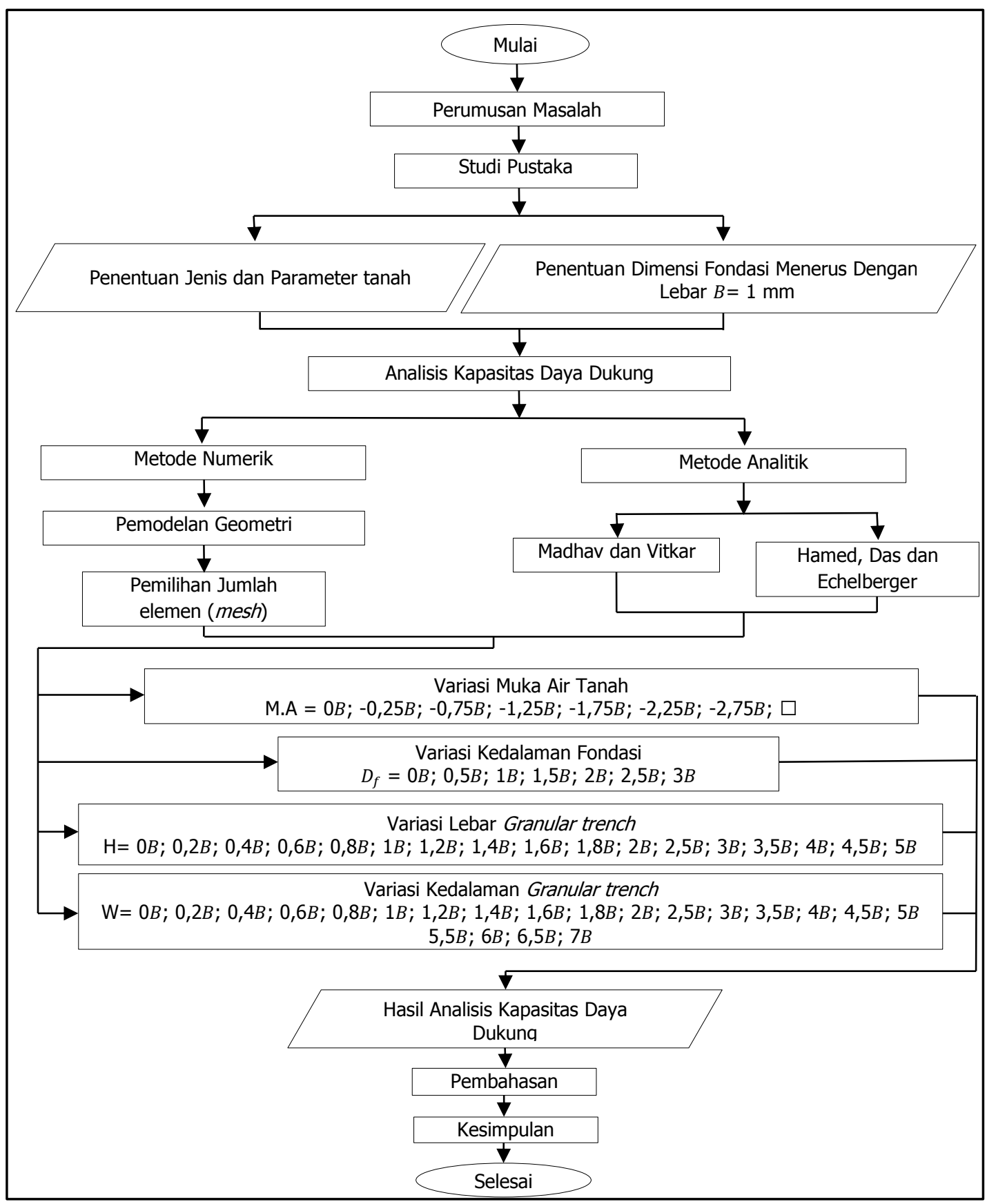

Gambar 5. Bangan alir fondasi dengan granular trench

\section{ANALISIS DATA}

\subsection{Umum}

Pemodelan fondasi dangkal pada tanah lempung lunak yang diperkuat granular trench menggunakan program PLAXIS 2D dengan jenis geometri berupa plainstrain 15-noded dan bentuk geometri penampang tanah, dilihat pada Gambar 6. Geometri penampang tanah dibuat dengan mesh lebih rapat di sekitar area pola keruntuhan fondasi dangkal memiliki lebar 10 meter dan kedalaman 5 meter, hal tersebut dimaksudkan agar akurasi mekanisme keruntuhan yang terjadi di sekitar area fondasi akan lebih akurat dan dapat mempersingkat proses running pada PLAXIS 2D. 


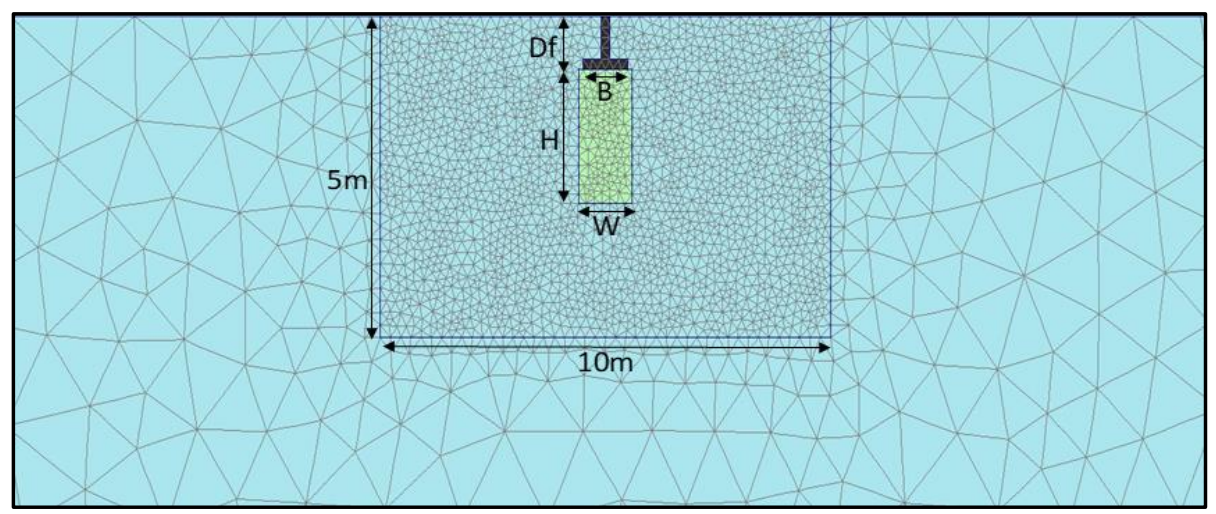

Gambar 6. Model geometri dan fondasi dangkal pada PLAXIS 2D

\subsection{Parameter Tanah dan Beton Fondasi Dangkal}

Jenis tanah yang digunakan dalam analisis kapasitas daya dukung fondasi dangkal pada tanah lempung lunak yang diperkuat granular trench adalah tanah lempung lunak yang memiliki pola keruntuhan geser setempat (Local Shear Failure) dan parameter tanah untuk granular trench memiliki pola keruntuhan geser umum (General Shear Failure). Data parameter tanah dan beton fondasi dangkal ditunjukan pada Tabel 1.

Tabel 1. Data Parameter Tanah

\begin{tabular}{ccccc}
\hline $\begin{array}{c}\text { Parameter } \\
\text { Tanah }\end{array}$ & Clay soil & Granular trench & Beton & Satuan \\
\cline { 1 - 2 }$\gamma_{\text {unsat }}$ & 16 & 17,5 & 25 & {$\left[\frac{\mathrm{kN}}{\mathrm{m}^{3}}\right]$} \\
\cline { 1 - 4 } $\boldsymbol{\gamma}_{\text {sat }}$ & 17 & 19 & & {$\left[\frac{\mathrm{kN}}{\mathrm{m}^{3}}\right]$} \\
\hline $\boldsymbol{\phi}$ & 0 & 40 & & {$[\mathrm{rad}]$} \\
\hline $\boldsymbol{c}$ & 10 & 0 & & {$\left[\frac{\mathrm{kN}}{\mathrm{m}^{2}}\right]$} \\
\hline $\boldsymbol{v}$ & 0,25 & 0,35 & 0,15 & {$[\mathrm{rasio}]$} \\
\hline $\boldsymbol{E}$ & 5.000 & 8.500 & 20.000 .000 & {$\left[\frac{\mathrm{kN}}{\mathrm{m}^{2}}\right]$} \\
\hline
\end{tabular}

\subsection{Hasil Analisis}

Dalam analisis menggunakan metode numerik dan analitik terdapat beberapa variabel yang dapat divariasikan antara lain variasi elevasi muka air tanah, variasi letak kedalaman fondasi, variasi lebar perbaikan tanah menggunakan granular trench, variasi kedalaman perbaikan granular trench yang bertujuan untuk mengetahui seberapa besar pengaruh dari elevasi muka air, letak kedalaman fondasi, lebar granular trench dan kedalaman granular trench terhadap kapasitas daya dukung.

\subsubsection{Variasi Muka Air Tanah}

Kondisi muka air tanah sangat berpengaruh terhadap nilai kapasitas daya dukung fondasi. Kondisi geometri dalam analisis adalah sebagai berikut, kedalaman fondasi $D_{f}=0 B$, lebar granular trench $W=1 B$, kedalaman granular trench $H=1 B$ dengan muka air tanah yang bervariasi, variasi elevasi muka air tanah dapat dilihat pada Gambar 7. 


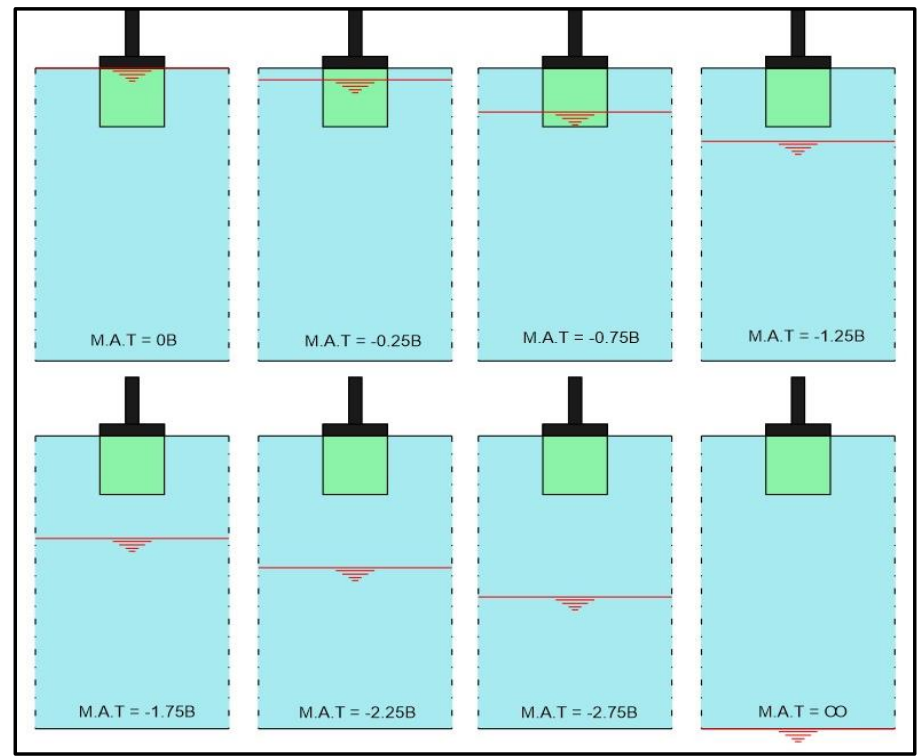

Gambar 7. Variasi elevasi muka air tanah

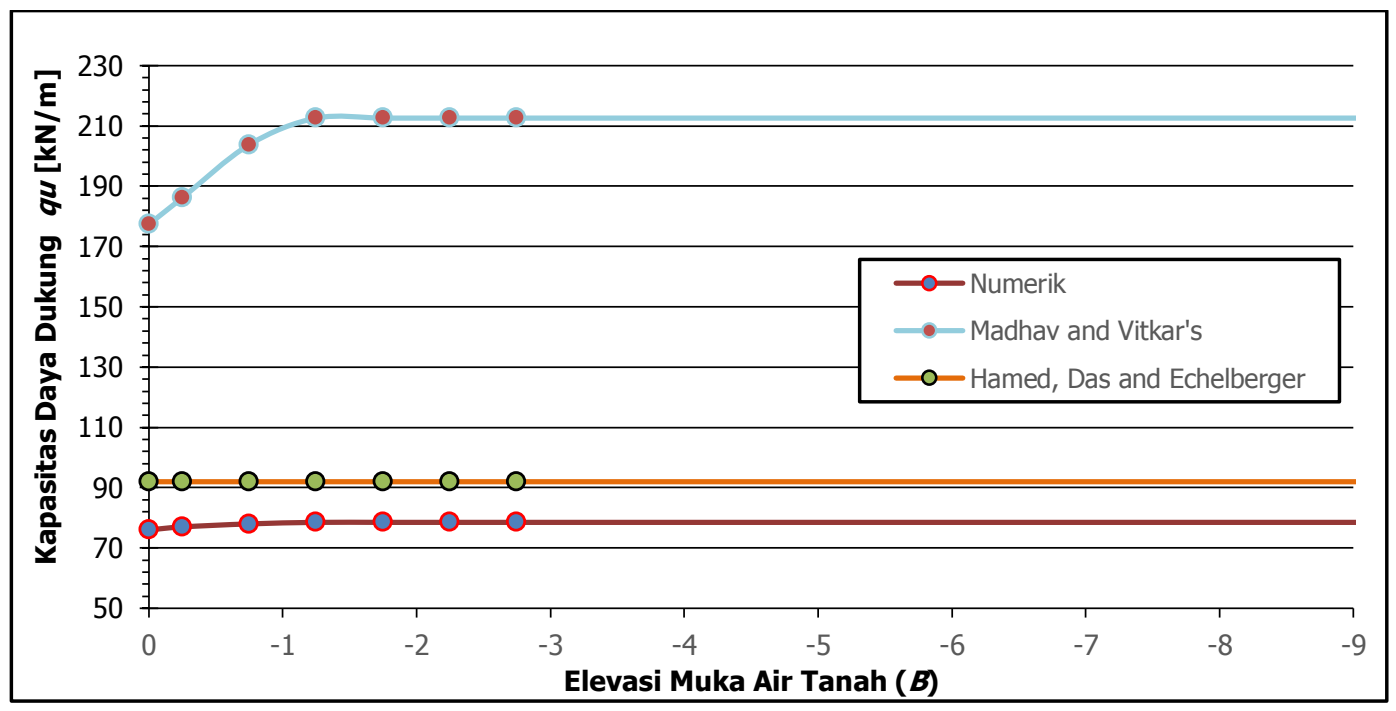

Gambar 8. Pengaruh muka air tanah terhadap daya dukung fondasi

Berdasarkan hasil analisis yang didapat, pengaruh elevasi muka air tanah terhadap nilai kapasitas daya dukung fondasi dangkal pada tanah lempung lunak yang diperbaiki dengan granular trench, adanya peningkatan kapasitas daya dukung antara metode numerik dan metode analitik Madhav and Vitkar's hingga kapasitas daya dukung fondasi menyentuh nilai maksimum pada elevasi muka air tanah $-1,25 B$ kemudian konstan setelahnya, terjadi perbedaan kapasitas daya dukung yang signifikan antara metode analitik Madhav and Vitkar's dengan metode numerik, sedangkan pada metode analitik Hamed, Das and Echelberger nilai kapasitas daya dukung fondasi cenderung konstan yang disebabkan oleh kedalaman fondasi $D_{f}=0 B$, dapat terlihat pada Gambar 8.

\subsubsection{Variasi Kedalaman Fondasi}

Dalam kasus fondasi dangkal pada tanah lempung lunak yang diperkuat dengan granular trench kondisi geometri dalam analisis adalah sebagai berikut, lebar granular trench $W=1 B$, kedalaman granular trench $H=1 B$, muka air tanah berada pada elevasi $O B$ (jenuh air) dengan kedalaman fondasi $D_{f}$ yang bervariasi, variasi kedalaman fondasi dapat dilihat pada Gambar 9. 


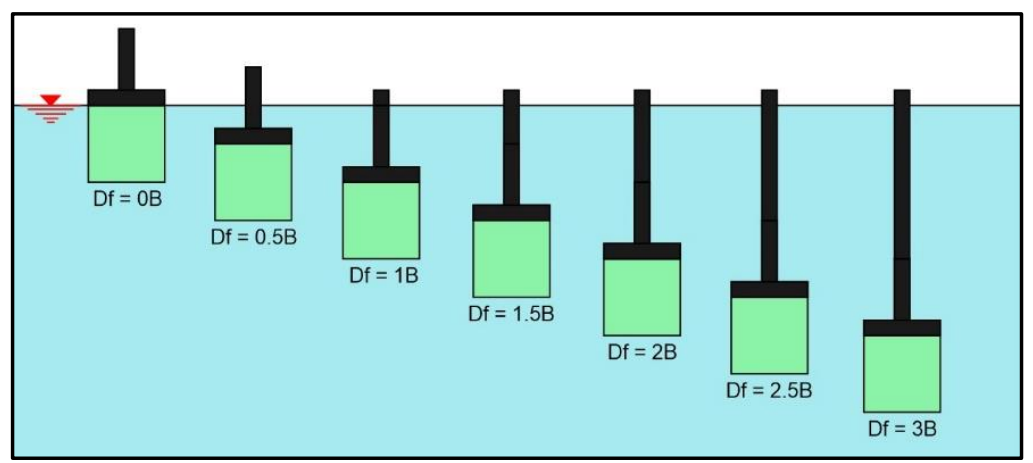

Gambar 9. Variasi kedalaman fondasi

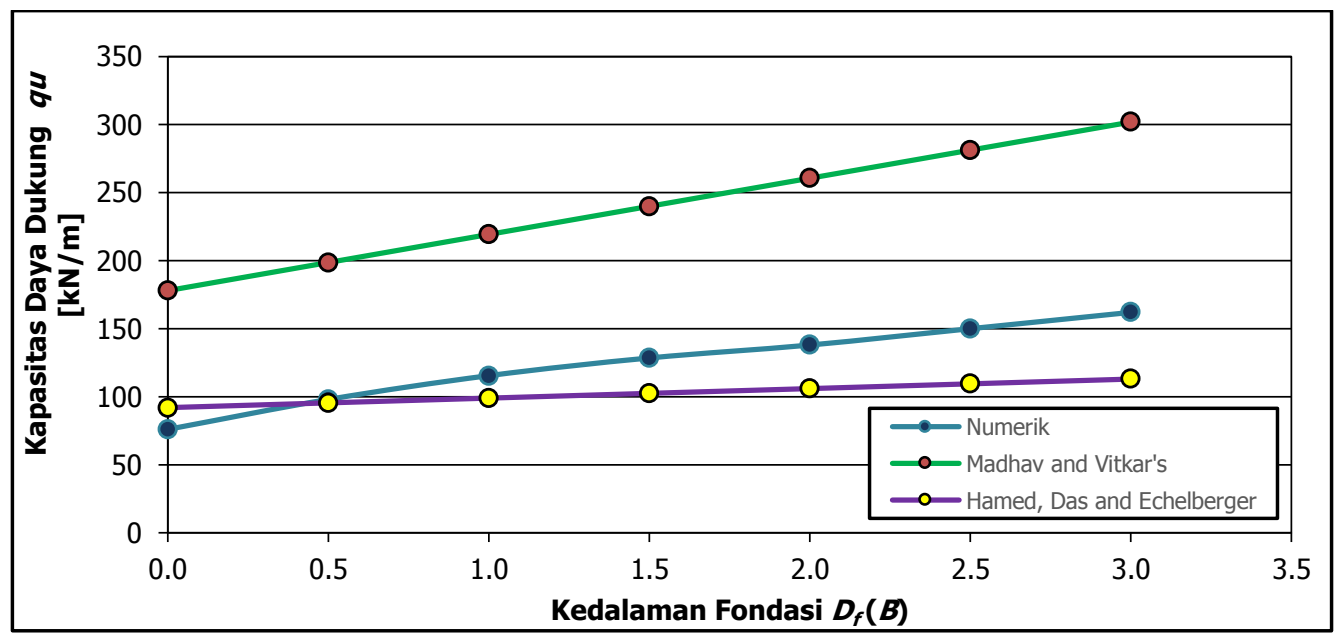

Gambar 10. Pengaruh kedalaman fondasi terhadap daya dukung fondasi

Berdasarkan hasil analisis, Pengaruh kedalaman fondasi terhadap kapasitas daya dukung fondasi dangkal pada tanah lempung lunak yang diperkuat granular trench, dari ketiga metode perhitungan menghasilkan nilai kapasitas daya dukung yang terus meningkat seiring bertambahnya kedalaman fondasi, akan tetapi perhitungan dengan metode analitik Madhav and Vitkar's menghasilkan nilai kapasitas daya dukung yang lebih besar dari metode numerik, sedangkan perhitungan dengan menggunakan metode analitik Hamed, Das and Echelberger, pengaruh kedalaman fondasi terhadap kapasitas daya dukung fondasi hanya mengalami sedikit peningkatan nilai kapasitas daya dukung tanah,dapat dilihat pada Gambar 10.

\subsubsection{Variasi Lebar Granular Trench}

Pengaruh lebar granular trench terhadap kapasitas daya dukung fondasi dangkal yang diperkuat dengan granular trench, kondisi geometri dalam analisis adalah sebagai berikut, kedalaman granular trench $H=1 B$, muka air tanah berada pada elevasi $0 B$ (jenuh air), kedalaman fondasi $D_{f}=0 B$ dengan lebar granular trench yang bervariasi, variasi lebar granular trench dapat dilihat pada Gambar 11. 


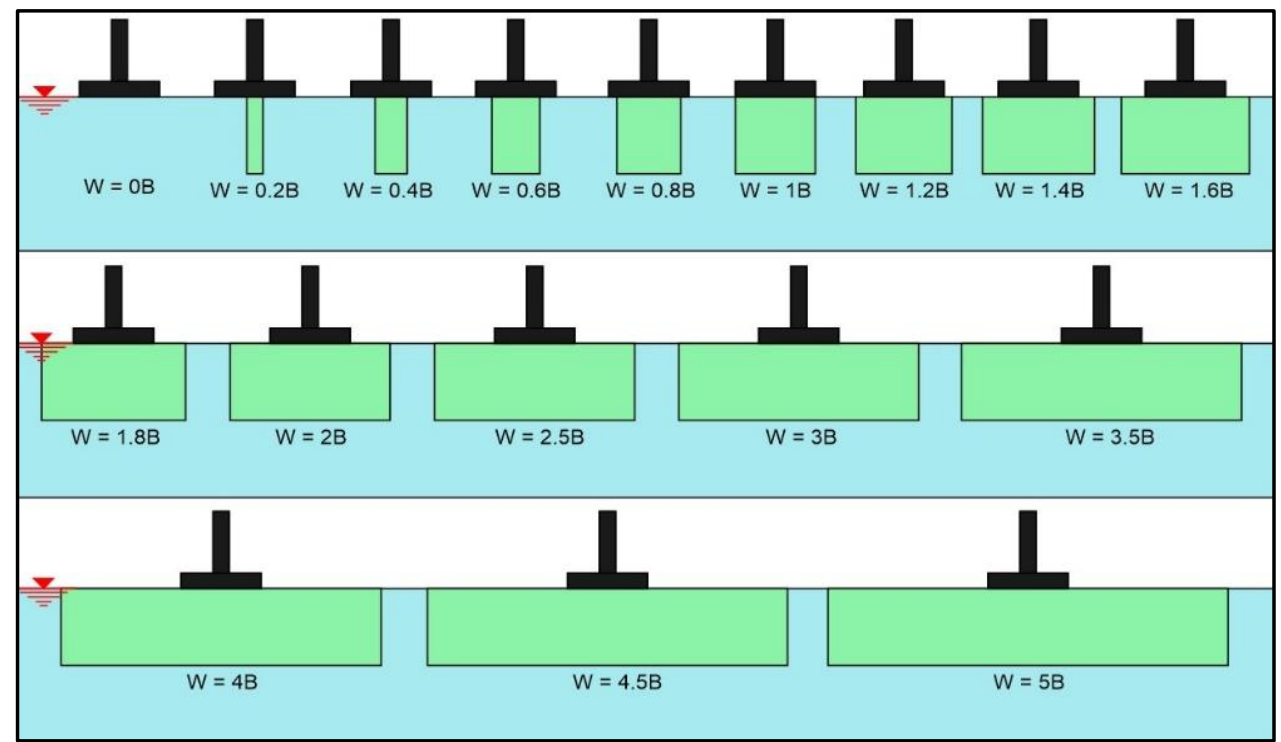

Gambar 11. Variasi lebar granular trench

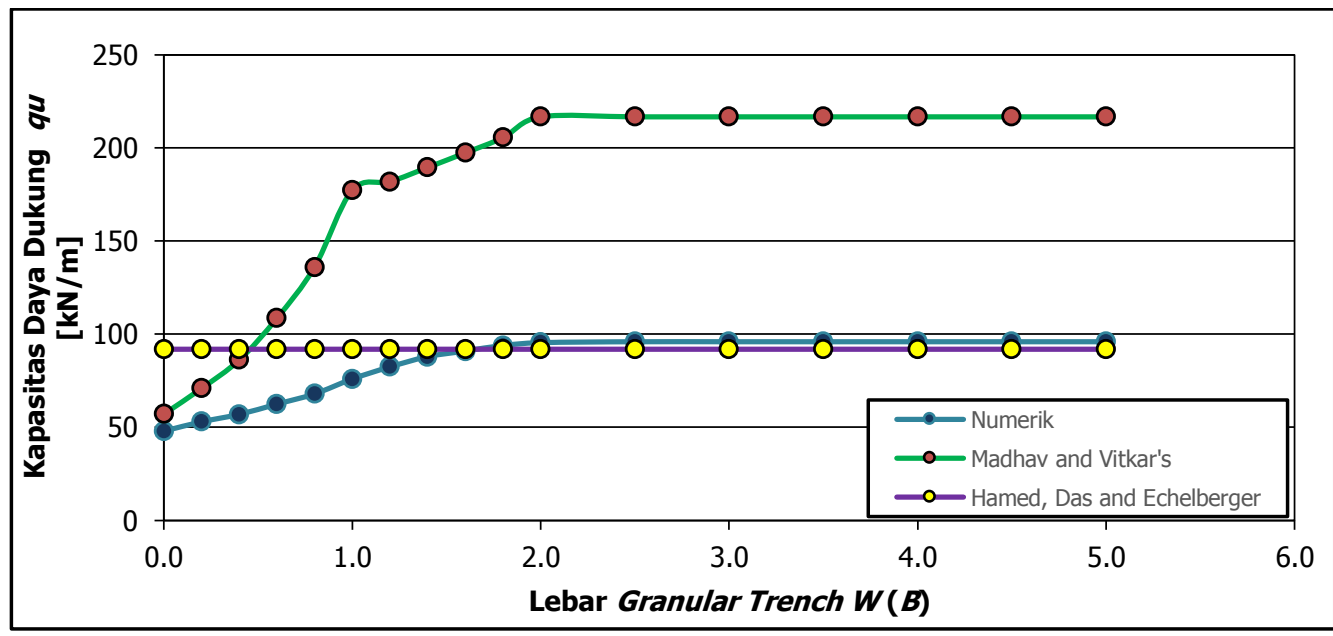

Gambar 12. Pengaruh lebar granular trench terhadap daya dukung fondasi

Berdasarkan hasil analisis yang didapat, pengaruh lebar granular trench terhadap nilai kapasitas daya dukung fondasi dangkal pada tanah lempung lunak yang diperbaiki dengan granular trench terjadi peningkatan kapasitas daya dukung fondasi dalam metode numerik dan metode analitik Madhav and Vitkar's seiring bertambahnya lebar granular trench, pada saat kapasitas daya dukung fondasi keduanya mencapai nilai maksimum dan konstan setelahnya, sedangkan perhitungan metode analitik Hamed, Das and Echelberger tidak terjadi peningkatan kapasitas daya dukung fondasi akan tetapi nilai kapasitas daya dukung fondasi menyerupai nilai kapasitas daya dukung fondasi maksimum pada metode numerik, dapat terlihat pada Gambar 12.

\subsubsection{Variasi Kedalaman Granular Trench}

Pengaruh kedalaman granular trench terhadap kapasitas daya dukung fondasi dangkal yang diperkuat dengan granular trench, kondisi geometri dalam analisis adalah sebagai berikut, muka air tanah berada pada elevasi 0B (jenuh air), kedalaman fondasi $D_{f}=0 B$, Terdapat dua variasi lebar granular trench yang berbeda yaitu lebar granular trench $W=2 B$ dengan kedalaman granular trench yang bervariasi, dapat dilihat pada Gambar 13. 


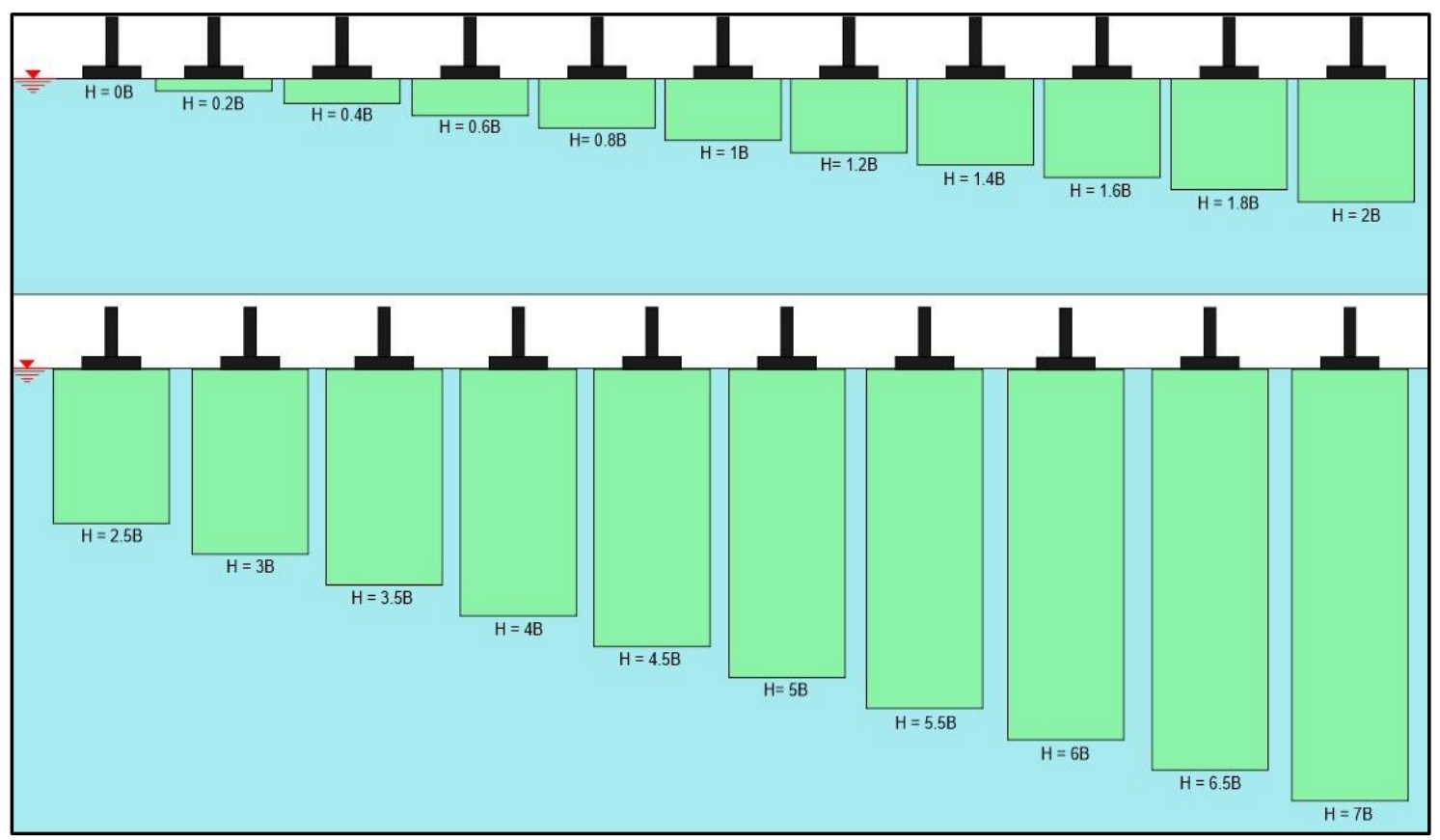

Gambar 13. Variasi kedalaman granular trench

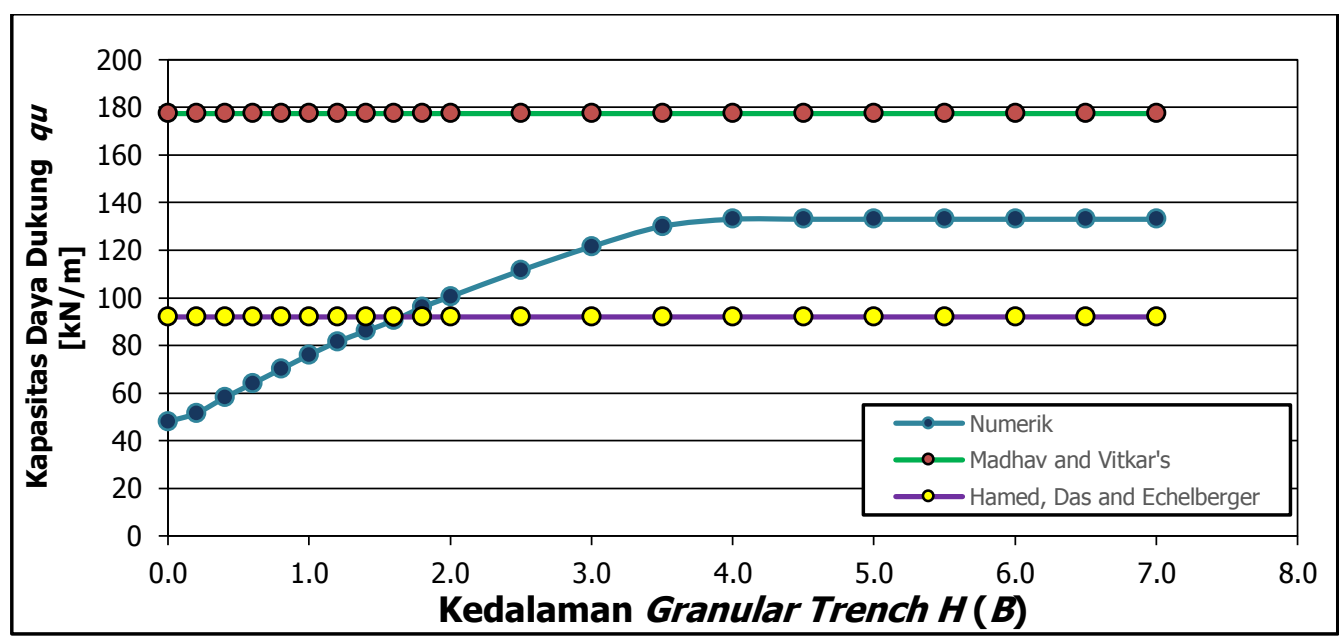

Gambar 14. Pengaruh kedalaman granular trench terhadap daya dukung fondasi

Berdasarkan hasil analisis yang didapat, pengaruh kedalaman granular trench terhadap nilai kapasitas daya dukung fondasi dangkal pada tanah lempung lunak yang diperbaiki dengan granular trench terjadi peningkatan kapasitas daya dukung fondasi seiring bertambahnya kedalaman granular trench dan saat kedalaman granular trench berada di sekitar $H=3,5 B$ kapasitas daya dukung fondasi mencapai nilai maksimum dan konstan setelahnya. Dalam perhitungan metode perhitungan analitik Madhav and Vitkar's dan Hamed, Das and Echelberger tidak terjadi peningkatan nilai kapasitas daya dukung fondasi yang dapat diartikan bahwa tidak adanya pengaruh variasi kedalaman granular trench terhadap kapasitas daya dukung fondasi, dapat terlihat pada Gambar 14.

\subsection{Pembahasan}

Dari ketiga metode perhitungan dengan menggunakan metode numerik dan metode analitik Madhav and Vitkar's dan Hamed, Das and Echelberger memiliki kekurangan dan kelebihannya masing-masing. Metode perhitungan analitik Hamed, Das and Echelberger memiliki kelebihan nilai kapasitas daya dukung fondasi sering kali mendekati nilai kapasitas daya dukung fondasi 
dengan perhitungan menggunakan metode numerik akan tetapi metode analitik Hamed, Das and Echelberger memiliki kekurangan yaitu terdapat beberapa faktor yang tidak diperhitungkan seperti faktor pengaruh elevasi muka air tanah, lebar perbaikan tanah dengan granular trench dan kedalaman perbaikan tanah dengan granular trench sehingga nilai kapasitas daya dukung tanah akan tetap konstan. Sedangkan perhitungan nilai kapasitas daya dukung fondasi dengan metode analitik Madhav and Vitkar's memiliki kelebihan yaitu terdapat beberapa faktor yang diperhitungkan seperti pengaruh elevasi muka air tanah, kedalaman fondasi dan lebar perbaikan granular trench terhadap nilai kapasitas daya dukung fondasi, akan tetapi metode Madhav and Vitkar's memiliki kekurangan yaitu nilai kapasitas daya dukung fondasi selalu memiliki nilai yang jauh lebih besar dibandingkan dengan perhitungan dengan metode numerik dan metode analitik Hamed, Das and Echelberger, sehingga perhitungan metode analitik Madhav and Vitkar's akan menghasilkan nilai kapasitas daya dukung fondasi yang mendekati nilai kapasitas daya dukung fondasi dengan menggunakan metode numerik apa bila nilai kapasitas daya dukung fondasi dengan metode analitik Madhav and Vitkar's dapat direduksi oleh faktor koreksi dengan nilai koefisien yang telah diperhitungkan yaitu 0,4-0,5 yang dapat menghasilkan nilai kapasitas daya dukung fondasi yang mendekati nilai kapasitas daya dukung fondasi dengan metode perhitungan numerik, dapat dilihat pada Gambar 15.

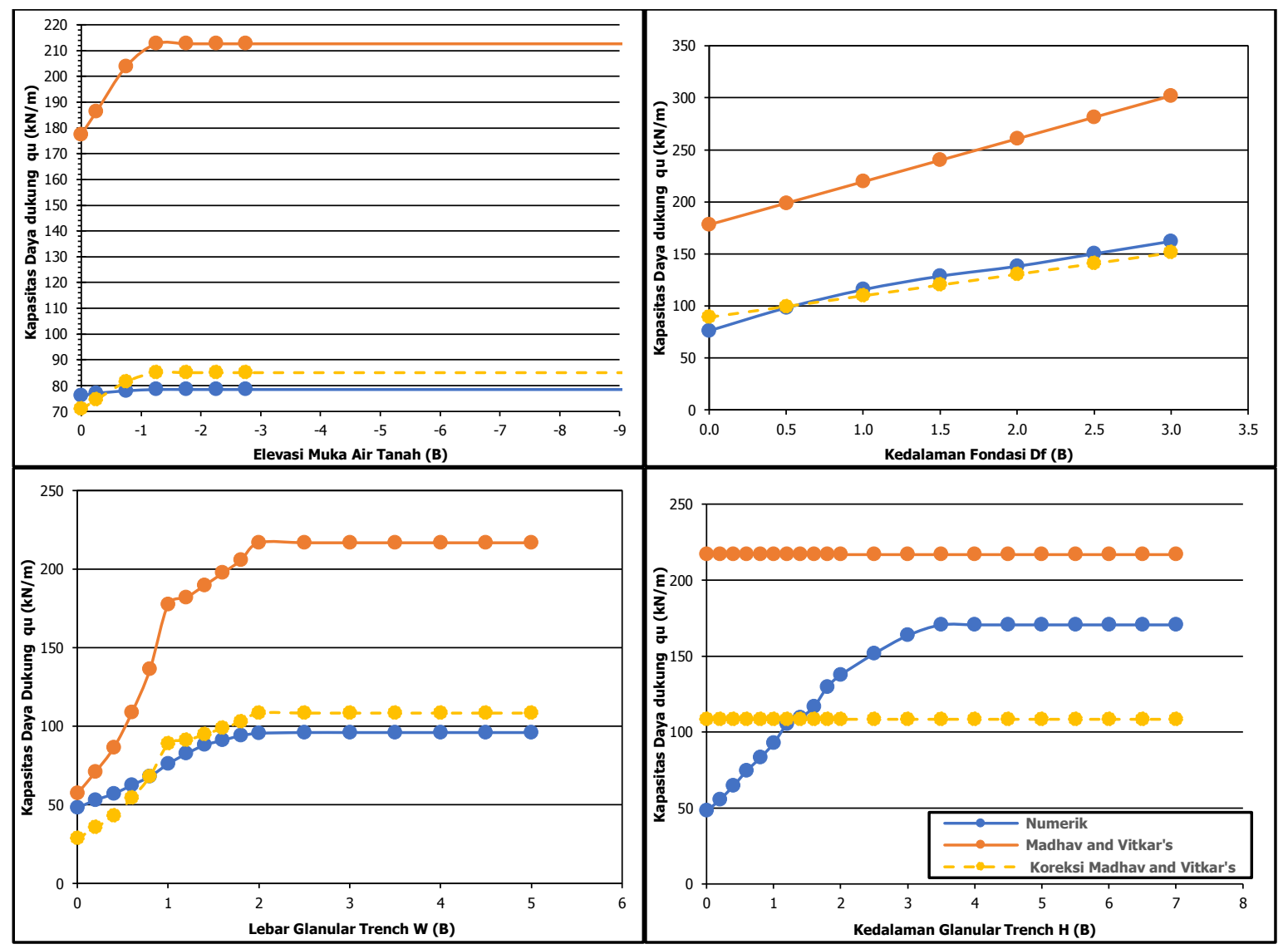

Gambar 15. Pengaruh faktor koreksi metode analitik Madhav and Vitkar's

\section{KESIMPULAN}

Adapun kesimpulan yang didapat pada penelitian ini adalah sebagai berikut:

1. Dalam perhitungan dengan metode numerik tipe kerapatan mesh yang dipilih adalah very fine, pada pemodelan tipe kerapatan mesh sangat berpengaruh terhadap hasil perhitungan kapasitas daya dukung fondasi, semakin rapat jumlah elemennya maka hasil perhitungan akan semakin akurat dan teliti. 
2. Terdapat keterbatasan dalam perhitungan dengan menggunakan metode analitik Madhav and Vitkar's yang disebabkan variabel yang tidak diperhitungkan yaitu pengaruh kedalaman granular trench, sehingga variabel yang divariasikan, tidak berpengaruh terhadap nilai kapasitas daya dukung fondasi.

3. Terdapat keterbatasan dalam perhitungan dengan menggunakan metode analitik Hamed, Das and Echelberger yang disebabkan beberapa variabel yang tidak diperhitungkan antara lain pengaruh lebar granular trench dan pengaruh kedalaman granular trench sehingga beberapa variabel yang divariasikan, tidak berpengaruh terhadap nilai kapasitas daya dukung fondasi.

4. Metode perhitungan analitik Madhav and Vitkar's selalu menghasilkan nilai kapasitas daya dukung fondasi yang lebih besar dibandingkan dengan perhitungan menggunakan metode numerik dan perhitungan metode analitik Hamed, Das and Echelberger, akan tetapi apabila nilai kapasitas daya dukung direduksi dengan nilai faktor koreksi 0,4-0,5 nilai kapasitas daya dukung fondasi akan menyerupai metode numerik.

5. Batasan pengaruh elevasi muka air tanah terhadap nilai kapasitas daya dukung fondasi yang diperkuat granular trench berada di sekitar lebih dari $1 B$.

6. Berdasarkan perhitungan menggunakan metode numerik dan metode perhitungan analitik Madhav and Vitkar's dan Hamed, Das and Echelberger, terjadi peningkatan nilai kapasitas daya dukung fondasi yang konstan, seiring dengan bertambahnya kedalaman fondasi $\left(D_{f}\right)$.

7. Berdasarkan perhitungan menggunakan metode numerik nilai kapasitas daya dukung fondasi maksimum terdapat pada kedalaman granular trench di sekitar $H=3,5 B$ dan lebar granular trench di sekitar $W=2 B$ dengan peningkatan nilai kapasitas daya dukung fondasi sebesar $355,2 \%$.

\section{DAFTAR RUJUKAN}

Budi, G. S. (2011). Pondasi Dangkal. Yogyakarta: Andi.

Das, B. M. (1999). Shallow Foundation: Bearing Capacity and Settlement. California: CRC Press.

Das, B. M. (2014). Principles of Foundation Engineering Eighth Edition. USA: Stamford, Cengange Learning.

Madhav, M. R., \& Vitkar, P. P. (1978). Strip Footing on Weak Clay Stabilized with a Granular Trench or Pile. Canadian Geotechnical Journal, 15(4), 605 - 609.

PLAXIS. (2016a). Reference Manual. Netherland: PLAXIS B.V.

PLAXIS. (2016b). Material Models Manual. Netherland: PLAXIS B.V. 